Public Health of Indonesia

Original Research

\title{
KNOWLEDGE AND ACTIONS OF LEPROSY PATIENTS ON THE INCIDENCE OF LEPROSY IN BRENGKOK VILLAGE, BRONDONG PUBLIC HEALTH CARE OF LAMONGAN REGENCY, INDONESIA
}

\author{
Alifatun Khunafa', Aries Prasetyo ${ }^{1}$, Trimawan Heru Wiyono ${ }^{1}$, Al Asyary ${ }^{2,3^{*}}$ \\ ${ }^{1}$ Study Program of Environmental Health, Health Polytechnic of Surabaya, Ministry of Health, Magetan, Indonesia \\ ${ }^{2}$ Department of Environmental Health, Faculty of Public Health, Universitas Indonesia, Depok, Indonesia \\ ${ }^{3}$ Center for Educational and Community Services (P3M), Faculty of Public Health, Universitas Indonesia, Depok, Indonesia
}

Received: 14 November 2019 | Accepted: 14 December 2019

DOI: http://dx.doi.org/10.36685/phi.v5i4.301

Correspondence:

Dr. Al Asyary, SKM., MPH

Department of Environmental Health, Faculty of Public Health, Universitas Indonesia, Depok, Indonesia

Email: al.asyary@ui.ac.id

Copyright: ( $)$ the author(s), YCAB publisher and Public Health of Indonesia. This is an open-access article distributed under the terms of the Creative Commons Attribution Non-Commercial License, which permits unrestricted non-commercial use, distribution, and reproduction in any medium, provided the original work is properly cited.

\begin{abstract}
Background: Leprosy is an infectious disease that can cause physical disability, as well as social, economic, and cultural problems. The prevalence of leprosy in Indonesia is still high.

Objective: The purpose of this study was to determine patients' behavioral factors that influence the incidence of leprosy.

Methods: An ex-post-facto analysis with a case-control approach was used. The population of the study was the entire Brengkok Village community. The sampling technique is a fixed-disease sampling method, in which the all cases ( 34 persons) are clinically proven leprosy sufferers and the controls (34 persons) are the comparable neighbors of the sufferers. Data analysis was done using a chi-square test, and the risk of disease was measured by the odd ratio (OR).

Results: Testing for differences between the case and the control group resulted in $p=0.000$ for knowledge about the cause of leprosy, $p=0.005$ for detecting an early sign of leprosy, $p=0.000$ for knowledge about the transmission of leprosy, and $p$ $=0.000$ for affecting the incidence of leprosy. The results showed that there was a relationship between the level of knowledge and the incidence of leprosy $(p=0.002)$, while the OR value obtained is 7.50 (CI: 2,168 - 25,946). Furthermore, testing for differences between the case and the control group yielded $p=1.000$ for the use of different clothes; $p=0.000$ for the use of different bathing tools; $p=0.000$ for the use of different towels, which means there is a connection between the use of towels and the incidence of leprosy; and $p=0.003$ for the use of different footwear. In addition, there is a relationship between the actions of people and the incidence of leprosy $(p=0.000)$, while the OR value obtained was 59,933 (CI: 13.131 - 273,557). Conclusion: The knowledge and actions of people affected by leprosy are predisposing factors associated with the incidence of leprosy and are risk factors for the disease. Knowledge about the transmission of leprosy and the activity of using different towels are the most important factors influencing the incidence of leprosy.
\end{abstract}

Keywords: knowledge, actions, leprosy, Indonesia

\section{BACKGROUND}

Leprosy disease is a contagious and infectious disease that can cause medical, social, economic, and cultural problems (Reibel, Cambau, \& Aubry, 2015). Leprosy can attack the skin, peripheral nerves, and other organs, causing the body to not function normally (Talhari, Talhari, \& Penna, 2015).

In 2016, there were 11,755 new recorded cases of leprosy, with East Java ranking first in the 
number of leprosy sufferers in Indonesia (Blok, De Vlas, \& Richardus, 2015). Lamongan Regency is one of the areas in East Java that face new cases of leprosy every year. The prevalence rate in Lamongan Regency has increased from 0.85 to 0.92 per 10,000 (Dinas Kesehatan Kabupaten Lamongan, 2018). In the data of the Brondong Public Health Center, the prevalence rate in Brondong Subdistrict was recorded to decrease from 1.95 to 1.33 per 10,000 , with 37 leprosy sufferers in 2013, 35 in 2014, 20 in 2015, 18 in 2016, and 14 in 2017 (Puskesmas Brondong, 2018). Brengkok Village is one of the villages with the highest leprosy incidence among other villages in Brondong Subdistrict, with 34 patients in total, of whom 15 with dry leprosy and 19 with wet leprosy (Dinas Kesehatan Kabupaten Lamongan, 2018; Puskesmas Brondong, 2018).

Environment and behavior, as well as health and hereditary factors, are factors that can influence health status (Asyary \& Mahendradhata, 2019; Asyary, Purwantyastuti, \& Junadi, 2017). Health behavior can be influenced by three kinds of factors: (1) predisposing factors, such as knowledge that can affect the behavior of patients, giving rise to a relationship between knowledge and the process of leprosy transmission; (2) enabling factors, such as the use of infrastructure, including bath soap and towels, and even the handling of products, which can all be a source of transmission; and (3) driving factors, either reinforcing or weakening, in the form of counseling, encouragement from health workers, and family support (Asyary, 2018; Asyary, Prasetyo, Eryando, \& Mahendradhata, 2019; Blok et al., 2015; Tosepu, Effendy, Imran, \& Asfian, 2015). This study determined the behavior of patients, especially predisposing factors, that influence the incidence of leprosy in the Village of Brengkok, Brondong Subdistrict, Lamongan Regency.

\section{METHODS}

\section{Study Design}

The study is an observational analytic study with a case-control design. Data collection took place from February to April 2018. Sampling was done using the 1:1 (case:control) of fixeddisease sampling method. Samples consisted of all 34 leprosy cases that were clinically proven over the last 5 years. For the controls, we used 34 non-sufferers who were characteristically comparable and lived around the patients' houses in Brengkok Village, Brondong Subdistrict, Lamongan Regency, and who were likely to be infected. The independent variable is the predisposing factor, including the level of knowledge and action. The dependent variable is the incidence of leprosy.

\section{Data Analysis}

Data analysis was done by means of a chisquare test, and the magnitude of risk was expressed as an odd ratio (OR).

\section{Ethical Consideration}

To fulfill research ethics, the researchers obtained a letter of application for research permission to conduct research at the local government from the National and Political Unity Agency (Kesbangpol) of Lamongan Regency review: 070/134/413.20/2018. Before conducting data collections with respondents, researchers always read the guidelines for data collections with respondents to obtain informed consent. The data was confidential and only researchers can access the data. This study also passed the Ethics Review from the Health Polytechnic of Surabaya, Ministry of Health, Magetan, Indonesia.

\section{RESULTS}

Table 1 shows the characteristics of the respondents in the case and control groups in Brengkok Village, Brondong Subdistrict, Lamongan Regency. By age, most of the respondents $(38.2 \%)$ were between 56 and 65 years old, while by gender, most of the respondents was $67.6 \%$ male. By occupational status, most of the respondents (44.1\%) worked as farmers; by educational status, most respondents $(76.5 \%)$ had an elementary education. 
Table 1 Characteristics of Respondents

\begin{tabular}{ll}
\hline Characteristics of Respondents & n (\%) \\
\hline Age & \\
12-16 years old & 2.9 \\
17-25 years old & 17.6 \\
26-35 years old & 17.6 \\
$36-45$ years old & 8.8 \\
46-55 years old & 8.8 \\
$56-65$ years old & 38.2 \\
$>65$ years old & 5.9 \\
\hline Gender & \\
Male & 67.6 \\
Female & 32.4 \\
\hline Work & \\
Civil servant & .0 \\
Private employee & 5.9 \\
Fisherman & 14.7 \\
Farmer & 44.1 \\
Does not work & 35.3 \\
\hline Education & \\
Elementary school & 76.5 \\
Junior high school & 2.9 \\
High school & 20.6 \\
College & .0 \\
\hline
\end{tabular}

Table 2 shows that there was a significant difference $(p=0.000)$ in the distribution of knowledge of respondents between the case and the control group, which means that there is a relationship between the respondents' knowledge about the causes of leprosy and the incidence of leprosy. The respondents' knowledge about the initial signs of leprosy is also significantly different ( $p=0.005$ ) between the two groups, which indicates a relationship between the respondents' knowledge about the initial signs of leprosy and the incidence of leprosy.

Likewise, the respondents' knowledge about leprosy transmission is different between the two groups $(p=0.000)$, implying that there is a relationship between the respondents' knowledge about leprosy disease and the incidence of leprosy. The same is true for the respondents' knowledge about the consequences of the occurrence of leprosy ( $p=$ 0.000), indicating a relationship between the knowledge about the consequences of leprosy and the incidence of leprosy.

Table 2 Distribution of Predisposing Factors

\begin{tabular}{lll}
\hline Predisposing Factors & $\boldsymbol{X}^{2}$ & $\boldsymbol{\rho}$ \\
\hline Knowledge & & \\
The cause of leprosy & 16.667 & 0.000 \\
Early signs of leprosy & 10.733 & 0.005 \\
Transmission of leprosy & 45.149 & 0.000 \\
The consequences of leprosy & 31.400 & 0.000 \\
\hline Action & & \\
Use of different clothes & 0.000 & 1.000 \\
Use of different bathing tools & 19.419 & 0.000 \\
Use of different towels & 27.495 & 0.000 \\
Use of different footwear & 8.658 & 0.003 \\
\hline
\end{tabular}

Table 2 shows that the distribution of respondents' actions regarding the use of clothes does not differ $(p=1.000)$ between the case and the control group, which means there is no relationship between the use of different clothes and the incidence of leprosy.

For the use of different bathing tools, $p=0.000$ was obtained, implying a relationship between the use of bathing tools and the incidence of leprosy. For the use of different towels, we obtained $p=0.000$, indicating a relationship between the use of different towels and the incidence of leprosy. Regarding the use of different footwear, we obtained $p=0.003$, which means that there is a relationship between the use of different footwear and the incidence of leprosy.

Table 3 Relationship between the Level of Knowledge and Actions and the Incidence of Leprosy

\begin{tabular}{lccccc}
\hline \multirow{2}{*}{ Variables } & \multicolumn{2}{c}{ The Incidence of Leprosy } & \multirow{2}{*}{ OR } & \multirow{2}{*}{$\mathbf{9 5 \%}$ CI } & \multirow{2}{*}{$\boldsymbol{\rho}$} \\
\cline { 2 - 5 } & Case & Control & & $2.168-25.946$ & 0.002 \\
\hline Knowledge & 17 & 4 & 7.50 & & \\
Poor & 17 & 30 & & & 0.000 \\
Fair & 29 & 3 & 59.933 & $13.131-273.557$ & \\
\hline Action & 5 & 31 & & & \\
$\quad$ Poor & & & & & \\
Fair & & & & & \\
\hline
\end{tabular}

Table 3 shows that for the relationship between the level of knowledge and the incidence of leprosy we obtained $p=0.002$, which means that there is a connection between both, while the OR value is 7.50 (CI: 2,168 - 25,946), so respondents with a poor knowledge have a 7.50 
times higher risk of attracting leprosy than respondents with a fair knowledge.

For the action, $p=0.000$ was obtained, which means that there is a relationship between action and the incidence of leprosy, while the OR value is 59,933 (CI: 13,131 - 273,557), so respondents with bad actions have a 59,933 times higher risk of attracting leprosy than respondents whose actions are good.

\section{DISCUSSIONS}

The results of this study show that for the knowledge of leprosy sufferers (cases), 17 respondents $(50 \%)$ had little knowledge and 17 respondents $(50 \%)$ had good knowledge. For the knowledge of non-leprosy sufferers (controls), it was found that four respondents $(11.8 \%)$ had little knowledge and 30 respondents $(88.2 \%)$ had good knowledge. The results showed that knowledge about the causes of leprosy, the initial signs of leprosy, and the transmission of leprosy are all related to the incidence of leprosy. The most relevant one is knowledge about the transmission of leprosy (Rachmani et al., 2019; Rahmawati, 2017). Most respondents did not know the method of transmission and thought that leprosy is transmitted through the air.

In the event of an illness, behavior is influenced by one's knowledge. Knowledge about a disease is crucial in shaping a person's actions. Therefore, knowledge is one of the predisposing factors of a person's behavior that can affect the incidence and severity of leprosy.

A study on disease knowledge in related setting showed that most respondents had little knowledge about leprosy (Lusli, Peters, Bunders, Irwanto, \& Zweekhorst, 2017). This situation causes respondents not to have sufficient access to the community (Lusli et al., 2017; Peters, 2015). In addition, lack of knowledge affects the regularity of treatment and influences the transmission process through direct contact with patients.

The low level of knowledge about leprosy can have a negative impact on the development of leprosy, such as physical disability and other bad consequences (Tosepu, Gunawan, Effendy, \& Fadmi, 2018). Good knowledge, on the other hand, can support good practice in order to minimize the incidence of leprosy (Indow, Pongtiku, Rantetampang, \& Mallongi, 2019). Better knowledge about leprosy can be achieved by counseling with the aim to change the behavior of people affected by leprosy (Amelia, Amiruddin, Arsin, Bahar, \& Palutturi, 2018; Rachmani, Lin, Hsu, Shidik, \& Noersasongko, 2018).

Most respondents who were not sick were wellinformed, so it may be concluded that the lower the level of knowledge of the respondents, the greater the chance of attracting leprosy. In this case, the leprosy sufferers' lack of knowledge concerned mainly the way in which leprosy is transmitted.

The results of the study show that for the actions of people affected by leprosy (cases), 29 respondents $(85.3 \%)$ had bad actions and five respondents $(14.7 \%)$ had good actions. For nonleprosy patients (controls), three respondents (8.8\%) had bad actions and 31 respondents $(91.2 \%)$ had good actions. The questionnaire results were obtained from four questions about the use of different clothes, the use of different bathing tools, the use of different towels, and the use of different footwear. Of these four aspects, the use of different towels is most strongly related to leprosy transmission; most leprosy patients use the same towels as their family members.

The action factor concerns the activities that are directly carried out in response to the disease, and they are predisposing factors for the development of leprosy (Susanti, Mahardita, Alfianto, Sujana, \& Susanto, 2018). Action is a factor that facilitates the entry of various diseases into the body if a person does not maintain his or her cleanliness (Lusli et al., 2017; Peters, 2015). On the other hand, if someone is able to maintain cleanliness, he or she can prevent the entry of various diseases (Aprizal, Lazuardi, \& Soebono, 2017). Bad actions can increase the risk of leprosy (Astutik \& Gayatri, 2018; Mallongi, Selomo, Rahman, 
Mattangang, \& Muhith, 2018). Good actions are taken to protect health in order to prevent the occurrence of leprosy.

\section{CONCLUSION}

Knowledge and actions of people affected by leprosy are predisposing factors associated with the incidence of leprosy and are risk factors for the incidence of leprosy. Knowledge about the transmission of leprosy and the action of using different towels are the two most important factors influencing the incidence of leprosy.

Declaration of Conflicting Interest

All authors have declared that there is no conflict of interest for this study.

Acknowledgment

This study was supported by several parties' favor that comprised of: Study Program of Environmental Health, Health Polytechnic of Surabaya, Ministry of Health, Magetan; Lamongan Regency's Local Government; Health Office, Social Office, and Youth Organization (Karang Taruna) of Brengkok Village at Brondong Subdistrict. We also thank to Directorat Research and Community Development (DRPM-UI), and the Faculty of Public Health, Universitas Indonesia (FKM-UI).

\section{REFERENCES}

Amelia, A. R., Amiruddin, R., Arsin, A. A., Bahar, B., \& Palutturi, S. (2018). Ex-Leprosy Patients Empowerment for Improving Living Quality through Empirical Rational Strategy in Makassar 2018. Indian Journal of Public Health Research \& Development, 9(10).

Aprizal, A., Lazuardi, L., \& Soebono, H. (2017). Faktor risiko kejadian kusta di Kabupaten Lamongan. Berita Kedokteran Masyarakat, 33(9), 427-432.

Astutik, E., \& Gayatri, D. (2018). Perceived Stigma in People Affected by Leprosy in Leprosy Village of Sinatala, Tangerang District, Banten Province, Indonesia. Kesmas: National Public Health Journal, 12(4), 187-193.

Asyary, A. (2018). Death outcome with successful treatment of tuberculosis patients. International Journal of Preventive Medicine, 9.

Asyary, A., \& Mahendradhata, Y. (2019). Unfinished first-line tuberculosis treatment in primary care in Indonesia. Family Medicine \& Primary Care Review (2), 185-188.

Asyary, A., Prasetyo, A., Eryando, T., \& Mahendradhata, Y. (2019). Predicting transmission of pulmonary tuberculosis in Daerah Istimewa Yogyakarta Province, Indonesia. Geospatial Health, 14(1)
Asyary, A., Purwantyastuti, E. T., \& Junadi, P. (2017). Perceived of healthcare utilization by adult pulmonary tuberculosis patients for their children in Yogyakarta. Asian Journal of Epidemiology, 10(2), 72-75.

Blok, D. J., De Vlas, S. J., \& Richardus, J. H. (2015). Global elimination of leprosy by 2020: are we on track? Parasites \& Vectors, 8(1), 548.

Dinas Kesehatan Kabupaten Lamongan. (2018). Profil Kesehatan Kabupaten Lamongan. Dinas Kesehatan Kabupaten Lamongan

Indow, O., Pongtiku, A., Rantetampang, A., \& Mallongi, A. (2019). Profile stigma of leprosy patients in manokwari district provinsi papua barat. International Journal of Science \& Healthcare Research, 4(1), 144-152.

Lusli, M., Peters, R., Bunders, J., Irwanto, I., \& Zweekhorst, M. (2017). Development of a rights-based counselling practice and module to reduce leprosy-related stigma and empower people affected by leprosy in Cirebon District, Indonesia. Leprosy Review, 88, 318-333.

Mallongi, A., Selomo, M., Rahman, S. A., Mattangang, A., \& Muhith, A. (2018). The Spatial Pattern and Risk Factors of Leprosy Occurrence in Barru, Indonesia. Indian Journal of Public Health Research \& Development, 9(8).

Peters, R. (2015). " I am not shy... so I don't have leprosy, right?": Understanding and assessing leprosyrelated stigma and the effect of stigma-reduction interventions in Cirebon District, Indonesia.

Puskesmas Brondong. (2018). Data kejadian penyakit Kusta wilayah kerja Puskesmas Brondong, Lamongan.

Rachmani, E., Hsu, C.-Y., Chang, P. W., Jumanto, J., Fuad, A., Ningrum, D. N., .. . Lin, M.-C. (2019). Encouraging On-time completion of leprosy patients treatment: implementing e-leprosy framework to primary health care in Indonesia. Asia Pacific Journal of Public Health, 1010539519847355.

Rachmani, E., Lin, M.-C., Hsu, C.-Y., Shidik, G. F., \& Noersasongko, E. (2018). Mining Medication behavior of the completion leprosy's multi-drug therapy in Indonesia. Paper presented at the 2018 International Seminar on Application for Technology of Information and Communication.

Rahmawati, I. (2017). The experiences of people affected by leprosy who participated in self-care groups in the community: A qualitative study in Indonesia. Leprosy Review, 88, 543-553.

Reibel, F., Cambau, E., \& Aubry, A. (2015). Update on the epidemiology, diagnosis, and treatment of leprosy. Medecine et Maladies Infectieuses, 45(9), 383-393.

Susanti, I. A., Mahardita, N. G., Alfianto, R., Sujana, I. M. I., \& Susanto, T. (2018). Social stigma, adherence to medication and motivation for healing: A cross-sectional study of leprosy patients at Jember Public Health Center, Indonesia. Journal of Taibah University Medical Sciences, 13(1), 97-102. 
Talhari, C., Talhari, S., \& Penna, G. O. (2015). Clinical aspects of leprosy. Clinics in Dermatology, 33(1), 26-37.

Tosepu, R., Effendy, D., Imran, L., \& Asfian, P. (2015). Epidemiology study of leprosy patients in the district of Bombana Southeast Sulawesi Province, Indonesia. International Journal of Research and Medical Science, 3(5), 12621265.

Tosepu, R., Gunawan, J., Effendy, D. S., \& Fadmi, F. R. (2018). Stigma and increase of leprosy cases in
SouthEast Sulawesi Province, Indonesia. African Health Sciences, 18(1), 29-31.

Cite this article as: Khunafa', A., Prasetyo, A., Wiyono, T. H., Asyary, A. Knowledge and actions of leprosy patients on the incidence of leprosy in Brengkok Village, Brondong Public Health Care of Lamongan Regency, Indonesia. Public Health of Indonesia.5(4). 99-104. http://dx.doi.org/10.36685/phi.v5i4.301 